\title{
HUBUNGAN PENGETAHUAN PERAWAT TENTANG PENCEGAHAN VENTILATOR ASSOCIATED PNEUMONIA (VAP) DENGAN PENINGKATAN ANGKA VAP DI RUANG ICU RUMAH SAKIT SARI ASIH KARAWACI TANGERANG 2016
}

\author{
Dewi Fitriani ${ }^{1}$, Puspa Wira Santi ${ }^{2}$ \\ Stikes Widya Dharma Husada Tangerang \\ e-mail :dewifitriani@wdh.ac.id
}

\begin{abstract}
ABSTRAK
Ventilator Associated Pneumonia (VAP) didefenisikan sebagai pneumonia yang terjadi 48 jam atau lebih setelah ventilator mekanik diberikan. Ventilator Associated Pneumonia (VAP) merupakan bentuk infeksi nosokomial yang paling sering ditemui di unit perawatan intensif (UPI), khususnya pada pasien yang menggunakan ventilator mekanik (Wiryana, 2007). Ventilator Associated Pneumonia (VAP) mempunyai banyak resiko. Akan tetapi, banyak intervensi keperawatan yang dapat menurunkan insiden VAP. Perawat sebagai ujung tombak pelayanan di Rumah Sakit khususnya perawat Intensive Care Unit ( ICU) perlu memiliki pemahaman dasar mengenai penggunaan ventilator mekanik dan mampu dalam pengelolaan, belum maksimalnya perawatan pasien yang terpasang ventilator, masih tingginya kejadian infeksi dan VAP di ruangan ICU pada pasien yang terpasang ventilator. Tujuan penelitian ini adalah untuk mengetahui hubungan Hubungan Pengetahuan Perawat Tentang Pencegahan Ventilator Associated Pneumonia (VAP) Dengan Peningkatan Angka VAP Di Ruang ICU Rumah Sakit Sari Asih Karawaci Tangerang. Desain penelitian analitik dengan pendekatan cross sectional. Analisis bivariat dalam penelitian ini menggunakan uji Independent T-test. Hasil univariat diperoleh tingkat pengetahuan tentang pencegahan VAP sebagian besar dalam kategori baik (77\%) dan kejadian VAP dengan angka CPIS $<6$ sebanyak 10 orang (77\%). Hasil uji statistik independent $t$-test diperoleh bahwa terdapat hubungan yang signifikan antara tingkat pengetahuan tentang pencegahan Ventilator Associated Pneumonia (VAP) dengan peningkatan angka VAP di Ruang ICU RS Sari Asih Karawaci Tangerang ( $p$ value 0.000<0.05). Saran bagi Rumah Sakit yaitu agar upaya pencegahan kejadian VAP di ICU RS lebih dikombinasikan, karena ada sebanyak 5 intervensi yang dapat dilakukan untuk mencegah VAP, atau yang biasa disebut VAP Bundle.
\end{abstract}

Kata Kunci : : VAP, CPIS, Pengetahuan, Perawat

\begin{abstract}
Ventilator Associated Pneumonia (VAP) is defined as pneumonia that occurs 48 hours or more after a given mechanical ventilator. Ventilator Associated Pneumonia (VAP) is a form of nosocomial infections are most commonly encountered in the intensive care unit (UPI), particularly in patients using mechanical ventilators (Wiryana, 2007). Ventilator Associated Pneumonia (VAP) have a higher risk. However, many nursing interventions can reduce the incidence of VAP. Nurses as the spearhead of service in hospitals especially nurses Intensive Care Unit (ICU) need to have a basic understanding of the use of a mechanical ventilator and capable in the management of patients, not maximal mounted ventilator patient care, with a high incidence of infection and VAP in ICU patients who mounted ventilator. The purpose of this study was to determine the relationship Relations Nurses Knowledge About the Prevention of Ventilator Associated Pneumonia (VAP) The VAP Score Improvement In ICU Hospital Sari Asih Karawaci Tangerang. Design of analytical research with cross sectional approach. The bivariate analysis in this study using a test Independent T-test. Univariate results obtained level of knowledge about the prevention of VAP mostly in good category (77\%) and the incidence of VAP with numbers CPIs <6 of 10 people (77\%). Statistical test results independent t-test showed that there is a significant relationship between the level of knowledge about the prevention of Ventilator Associated Pneumonia (VAP) with increased rates of VAP in ICU Sari Asih Hospital in Karawaci ( $p$ value 0.000> 0.05). Suggestions for Hospital namely that efforts to prevent the incidence of VAP in ICU Hospital be combined, because there are as many as five possible interventions to prevent VAP, or so-called VAP Bundle
\end{abstract}

Keywords: VAP, CPIs, Knowledge, Nurses 


\section{Pendahuluan}

Infeksi nosokomial merupakan suatu masalah yang nyata di seluruh dunia dan terus meningkat. Kejadian infeksi nosokomial berkisar dari terendah sebanyak $1 \%$ di beberapa negara di Eropa dan Amerika hingga $40 \%$ di beberapa tempat Asia, Amerika Latin dan Sub-Sahara Afrika. Pada tahun 1987, suatu survey prevalensi meliputi 55 rumah sakit di 14 negara berkembang pada tempat wilayah penderita infeksi nosocomial. Pada survei ini frekuensi tertinggi dilaporkan dari rumah sakit diwilayah Timur Tengah Mediterania dan Asia Tenggara, masing-masing $11,8 \%$ dan $10 \%$. Penelitian WHO dan lain-lain, juga menemukan prevalensi infeksi nosokomial yang tertinggi terjadi di Intensive Care Unit (ICU), perawatan bedah akut, dan bangsal ortopedi (Tietjen, 2004).

Dampak infeksi nosokomial menambahkan ketidakberdayaan fungsional tekanan emosional dan kadang-kadang pada beberapa kasus akan menyebabkan kecacatan sehingga menurunkan kualitas hidup.
Sebagai tambahan infeksi nosoko mial sekarang juga merupakan salah satu penyebab kematian. Dampak infeksi nosokomial lebih jelas di negara miskin terutama yang dilanda HIV/, AIDS, karena temuan terakhir membuktikan bahwa pelayanan medis yang tidak aman merupakan faktor penting dalam transmisi HIV (Tietjen, 2004).

Tindakan perawatan ventilasi mekanik merupakan salah satu aspek kegiatan perawat dalam memberikan asuhan keperawatan sehari-hari dalam fungsi independen dan interdependen dengan tim medis. Dalam tindakan perawatan ventilasi mekanik perawat harus berhati-hati karena mempunyai resiko yang besar seperti terjadinya infeksi nosokomial pneumonia (Hudak, 2007).

Kebanyakan pneumonia nosokomial terjadi melalui aspirasi bakteri yang hidup di belakang tenggorokan (orofaring) atau lambung. Intubasi dan ventilasi mekanik sangat meningkatkan resiko infeksi karena menghalangi mekanisme pertahanan tubuh, batuk, bersin, dan reflek muntah mencegah aksi dari pembersihan rambut (silia) dan sel 
yang mengeluarkan mucus dari system pernafasan atas ; dan memberikan jalan langsung masuknya mikroorganisme ke paruparu. Prosedur lain yang dapat meningkatkan resiko infeksi meliputi terapi oksigen, terapi pernafasan tekanan positif intermiten dan pengisapan endotrakeal (Tietjen, 2004).

\section{Ventilator Associated Pneumonia} (VAP) didefenisikan sebagai pneumonia yang terjadi 48 jam atau lebih setelah ventilator mekanik diberikan. Ventilator Associated Pneumonia (VAP) merupakan bentuk infeksi nosokomial yang paling sering ditemui di unit perawatan intensif (UPI), khususnya pada pasien yang menggunakan ventilator mekanik (Wiryana, 2007).

Diagnosa Ventilator Associated Pneumonia (VAP) secara klinis ditegakkan berdasarkan adanya demam (> 38,30 C), leukositosis (> $10.000 \mathrm{~mm} 3)$, sekret trakea berna 3 dan adanya infiltrat yang baru atau menetap dari radiologi. Definisi tersebut mempunyai sensitifitas yang tinggi namun spesifisitasnya rendah (Joseph dkk, 2010). Diagnosa
Ventilator Associated Pneumonia (VAP) dengan spesifisitas yang tinggi dapat dilakukan dengan menghitung Clinical Pulmonary Infection Score (CPIS) yang mengkombinasikan data klinis, laboratorium, perbandingan tekanan oksigen dengan fraksi oksigen ( $\mathrm{PaO} 2 / \mathrm{FiO} 2)$ dan foto toraks (Luna, 2003).

Ventilator Associated Pneumonia (VAP) merupakan komplikasi di sebanyak $28 \%$ dari pasien yang menerima ventilasi mekanik. Kejadiannya meningkat seiring dengan peningkatan durasi penggunaan ventilasi mekanik. Estimasi insiden adalah sebesar 3\% per hari selama 5 hari pertama, $2 \%$ per hari selama 6-10 hari, dan 1\% per hari setelah 10 hari (Amanullah \& Posner, 2010). Insiden Ventilator Associated Pneumonia (VAP) pada pasien yang mendapat ventilasi mekanik sekitar 22,8 \%, dan pasien yang mendapat ventilasi mekanik menyumbang sebanyak $86 \%$ dari kasus infeksi nosokomial. Selanjutnya resiko terjadinya pneumonia meningkat 3 sampai 10 
kali lipat pada pasien yang mendapat ventilasi mekanik (Agustyn, 2007).

Salah satu bentuk pneumonia nosokomial yang terjadi pada klien yang menggunakan ventilasi mekanik dan intubasi. Kuman penyebab infeksi ini tersering berasal dari gram negative (Dahlan, 2006). Rekam medik Intensive Care Unit (ICU) Rumah Sakit St.Borromeus Bandung mencatat angka kejadian infeksi nosokomial pneumonia $24 \%$ dengan angka mortalitas 33,33\% (Regina, 2006). Rekam medik Rumah Sakit Hasan Sadikin Bandung mencatat $47 \%$ infeksi nosokomial pneumonia pada pasien yang menggunakan ventilasi mekanik dan intubasi (Dahlan,2006).
Data Bulan Januari-Agustus 2015 menunjukkan jumlah pasien yang terpasang ventilator dan yang didiagnosa pneumonia. Pasien yang didiagnosa pneumonia dalam hal ini adalah pasien yang setelah hari ke 6 dilakukan pemeriksaan kultur sputum dan foto thorak hasilnya menunjukkan pneumonia. Dalam pengumpulan data ini telah mengeluarkan pasien yang saat masuk didiagnosa Penyakit Paru Obstruksi Menahun (PPOM) dan Tuberculosis (TBC).

Tabel 1. Jumlah Pasien Yang Terpasang Ventilator Dan Yang Didiagnosa Pneumonia Per Bulan, Mulai Bulan Januari-Agustus 2015

\begin{tabular}{|c|c|c|c|}
\hline No & Bln & $\begin{array}{l}\text { Pasien } \\
\text { Ventilator }\end{array}$ & Kejadian Pneumonia (orang) \\
\hline 1 & Jan & 7 & 3 \\
\hline 2 & Feb & 10 & 3 \\
\hline 3 & Maret & 8 & 2 \\
\hline 4 & April & 10 & 2 \\
\hline 5 & Mei & 8 & 1 \\
\hline 6 & Juni & 4 & 0 \\
\hline 7 & Juli & 11 & 0 \\
\hline 8 & Agust & 16 & 0 \\
\hline Total & & 75 & 11 \\
\hline
\end{tabular}

Sumber :Rekam Medik RS.Sari Asih Karawaci Tangerang, 2015 
Ventilator Associated Pneumonia (VAP) mempunyai banyak resiko. Akan tetapi, banyak intervensi keperawatan yang dapat menuru 4 insiden VAP. Tindakan yang dapat dilakukan untuk mencegah VAP diantaranya cuci tangan dan pemakaian sarung tangan sebelum dan sesudah melakukan tindakan, dekontaminasi oral, intervensi farmakologis oral, stress ulcer prophilaxis, pengisapan sekret endotrakeal, perubahan posisi klien, posisi semi-fowler, pengisapan sekret orofaring dan pemeliharaan sirkuit ventilator (Agustyn, 2007).

Perawat sebagai ujung tombak pelayanan di rumah sakit khususnya perawat Intensive Care Unit ( ICU)

perlu memiliki pemahaman dasar mengenai penggunaan ventilator mekanik dan mampu dalam pengelolaan pasien dengan ventilator mekanik yang meliputi: Perawatan jalan napas, perawatan endotrakeal, tekanan manset selang (cuff tube), perawatan gastro intestinal, dukungan nutrisi, perawatan mata dan perawatan psikolgis pasien (Purnawan dan Saryono, 2010).
Pengetahuan yang harus dimiliki oleh perawat sebagai pemberi perawatan tehadap pasien yang di rawat di ICU harus mampu melakukan perawatan yang sesuai dengan masalah yang dihadapi pasien, kemampuan dalam melakukan perawatan pada pasien di ICU diperoleh dengan cara pelatihan khusus ICU. pelatihan yang harus dimiliki oleh seorang perawat ICU mencakup: Pelatihan pemantauan (monitoring), pelatihan ventilasi mekanik. Pelatihan terapi cairan, eletrolit, dan asambasa, pelatihan penatalaksanaan infeksi dan pelatihan manajemen ICU. Pelatihan yang dimaksud di atas merupakan modal utama perawat ICU dalam melakukan perawatan terhadap pasien yang dirawat di ICU, masalah yang dialami oleh perawat ICU yang bekerja di ruangan ICU Rumah Sakit. Sari Asih Karawaci Tangerang masih banyak perawat yang belum mendapat pelatihan di atas sehingga dalam memberi perawatan kepada pasien masih mendapat kendala, jumlah perawat ICU RS. Sari Asih Karawaci Tangerang sebanyak 13 orang, 3orang (23\%) sudah 
mendapat pelatihan khusus ICU, 10 orang $(77 \%)$ belum mendapatkan pelatihan khusus ICU (Data Kepegawaian Instalasi Perawatan Intensif, 2012).

Berdasarkan inti fenomena diatas dan mengingat pentingnya intervensi keperawatan yang baik dan benar dalam rangka pencegahan VAP oleh karena itu peneliti tertarik untuk melakukan penelitian tentang

Hubungan Pengetahuan Perawat Tentang Pencegahan Ventilator Associated Pneumonia (VAP) Dengan Peningkatan Angka VAP Di Ruang ICU Rumah Sakit Sari Asih Karawaci Tangerang

\section{Metode}

Jenis Penelitian ini menggunakan analitik dengan pendekatan cross sectional bertujuan untuk memperoleh hasil kuantitas Hubungan Pengetahuan Perawat
Tentang Pencegahan Ventilator Associated Pneumonia (VAP) Dengan Peningkatan Angka VAP Di Ruang ICU Rumah Sakit Sari Asih Karawaci Tangerang.

\section{Hasil}

Pengumpulan data dilakukan pada bulan Februari 2016 terhadap 13 responden yaitu perawat di ruang ICU RS Sari Asih Karawaci Tangerang. Hasil pengolahan data disajikan dalam bentuk diagram/tabel univariat dan bivariat

Tabel 5.1. Distribusi Frekuensi Pengetahuan Perawat Tentang Pencegahan Ventilator Associated Pneumonia (VAP) di Ruang ICU RS Sari Asih Karawaci Tangerang

\begin{tabular}{clcc}
\hline No & \multicolumn{1}{c}{$\begin{array}{c}\text { Pengeta } \\
\text { huan }\end{array}$} & Jumlah (n) & Persen (\%) \\
\hline 1. & Baik & 10 & 77 \\
\hline 2. & Kurang & 3 & 23 \\
\hline & Total & 13 & 100 \\
\hline
\end{tabular}


Berdasarkan tabel 5.1 diatas dapat terbanyak pada kategori baik yaitu diketahui pengetahuan responden sebanyak 10 orang $(77 \%)$

Tabel 5.2 : Indikator Komponen CPIS pada pasien di Ruang ICU RS Sari Asih Karawaci Tangerang

\begin{tabular}{|c|c|c|c|}
\hline No & Indikator Komponen & $\mathbf{N}$ & $\%$ \\
\hline \multirow[t]{5}{*}{1} & Suhu & $\mathbf{N}$ & $\%$ \\
\hline & $\geq 36,5$ dan $\leq 38,4$ & 5 & 38 \\
\hline & $\geq 38,5$ dan $\leq 38,9$ & 4 & 31 \\
\hline & $\geq 39,0$ dan $\leq 36,0$ & 4 & 31 \\
\hline & Total & 13 & $100^{\circ}$ \\
\hline \multirow[t]{4}{*}{2} & Leukosit & $\mathbf{N}$ & $\%$ \\
\hline & $\geq 4000$ dan $\leq 11000$ & 0 & 0 \\
\hline & $<4000$ dan $>11000$ & 13 & 100 \\
\hline & Total & 13 & $100^{\circ}$ \\
\hline \multirow[t]{5}{*}{3} & Sekret Trakea & $\mathbf{N}$ & $\%$ \\
\hline & Sedikit & 1 & 8 \\
\hline & Sedang & 7 & 54 \\
\hline & Banyak & 5 & 38 \\
\hline & Total & 13 & 100 \\
\hline \multirow[t]{4}{*}{4} & $\mathrm{PaO}_{2} / \mathrm{FiO}_{2}$ & $\mathbf{N}$ & $\%$ \\
\hline & $>240$ atau ada ARDS & 0 & 0 \\
\hline & $\leq 240$ atau tidak ARDS & 13 & 100 \\
\hline & $\begin{array}{l}\text { Total } \\
\end{array}$ & 13 & $100^{\circ}$ \\
\hline \multirow[t]{5}{*}{5} & $\begin{array}{r}\text { Foto Torak } \\
\end{array}$ & $\mathbf{N}$ & $\%$ \\
\hline & Tidak ada infiltrat & 0 & 0 \\
\hline & Infiltrat difus & 2 & 15 \\
\hline & Infiltrat terlokalisir & 11 & 85 \\
\hline & Total & 13 & $100^{\circ}$ \\
\hline
\end{tabular}

Berdasarkan tabel 5.2 diatas dapat dilihat bahwa pasien dengan suhu $\geq$ 36,5 dan $\leq 38,4$ sebanyak $38 \%$, hasil leukosit < 4000 dan > 11000 sebanyak $100 \%$, secret trakea sedang sebanyak $54 \%$, nilai $\mathrm{PaO} 2$ /
FiO2 $\leq 240$ atau tidak ada ARDS sebanyak $100 \%$, dan hasil foto thorax infiltrate terlokalisir sebanyak $85 \%$. 
Tabel 5.3 : Distribusi Skor CPIS pada Pasien VAP

\begin{tabular}{ccc}
\hline Skor CPIS & $\mathbf{N}$ & $\%$ \\
\hline$<6$ & 10 & 77 \\
\hline$\geq 6$ & 3 & 23 \\
\hline Total & 13 & 100 \\
\hline
\end{tabular}

Berdasarkan tabel 5.3, dapat diketahui bahwa skor CPIS yang berjumlah 6 sebanyak 10 orang

(77\%) dan yang berjumlah 7 sebanyak 3 orang (23\%).

Tabel 5.4 : Distribusi Frekuensi Hubungan Pengetahuan Perawat Tentang Pencegahan VAP Dengan Peningkatan Angka VAP di Ruang ICU RS Sari Asih Karawaci Tangerang

\begin{tabular}{cccccccc}
\hline \multirow{2}{*}{$\begin{array}{c}\text { Pengetahuan } \\
\text { Perawat }\end{array}$} & \multicolumn{2}{c}{ Tidak } & Ya & & Total & & P value \\
\cline { 2 - 7 } & $\mathbf{N}$ & $\%$ & $\mathbf{N}$ & $\%$ & $\mathbf{N}$ & $\%$ & \\
\hline Baik & 9 & 90 & 1 & 10 & 10 & 100 & 0.000 \\
\hline Kurang & 1 & 33.3 & 2 & 66.67 & 3 & 100 & \\
\hline Total & 10 & 76.9 & 3 & 23.1 & 13 & 100 & \\
\hline
\end{tabular}

Berdasarkan tabel 5.4 diatas dapat dilihat bahwa pengetahuan perawat dengan kategori baik sebanyak 10 orang $(76.9 \%)$, dengan tidak adanya peningkatan angka VAP sebanyak 9 orang $(90 \%)$ dan sisanya sebanyak 1 orang (10\%) dengan ada peningkatan angka VAP. Sedangkan pengetahuan perawat dengan kategori kurang sebanyak 3 orang (23.1\%), dengan adanya tidak ada peningkatan angka VAP sebanyak 1 orang (33.3\%) dan sisanya sebanyak 2 orang $(66.7 \%)$ dengan ada peningkatan angka VAP
PEMBAHASAN

ANALISA UNIVARIAT

Tingkat Pengetahuan Perawat

Tentang Pencegahan Ventilator Associated Pneumonia (VAP)

Berdasarkan hasil penelitian pada tabel 5.1 diketahui bahwa tingkat pengetahuan pengetahuan responden tentang pencegahan VAP terbanyak pada kategori baik yaitu sebanyak 10 orang $(77 \%)$.

Menurut Notoatmodjo (2010) pengetahuan adalah hasil dari tahu 
dan hal ini terjadi setelah orang melakukan penginderaan terhadap objek tertentu. Sebagian besar pengetahuan manusia diperoleh dari pendidikan, pengalaman diri sendiri maupun orang lain, media massa, maupun lingkungan.

Pengetahuan tentang pencegahan VAP merupakan hasil dari tahu dan hal ini tenjadi setelah orang melakukan penginderaan terhadap pengetahuan ini.Selain penginderaan. juga dengan penciuman rasa. dan raba. Sebagian besar pengetahuan manusia diperoleh melalui mata dan telinga. Pengetahuan ini juga rnerupakan domain (kawasan) yang sangat penting untuk terbentuknya perilaku dalam mempraktekkan tentang pencegahan VAP $\mathrm{k} \quad 3$ oPengetahuan yang harus dimiliki oleh perawat sebagai pemberi perawatan tehadap pasien yang di rawat di ICU harus mampu melakukan perawatan yang sesuai dengan masalah yang dihadapi pasien, kemampuan dalam melakukan perawatan pada pasien di ICU diperoleh dengan cara pelatihan khusus ICU. pelatihan yang harus dimiliki oleh seorang perawat ICU mencakup: Pelatihan pemantauan (monitoring), pelatihan ventilasi mekanik. Pelatihan terapi cairan, eletrolit, dan asam-basa, pelatihan penatalaksanaan infeksi dan pelatihan manajemen ICU.

Pelatihan tersebut merupakan modal utama perawat ICU dalam melakukan perawatan terhadap pasien yang dirawat di ICU. Diketahui jumlah perawat ICU RS Sari Asih Karawaci adalah sebanyak 13 orang dan sebanyarang (23\%) sudah mendapat pelatihan $\mathrm{kh} 7$ ICU, 10 orang (77\%) belum mendapatkan pelatihan khusus ICU (Data Kepegawaian Instalasi Perawatan Intensif, 2012).

Menurut peneliti tingkat pengetahuan perawat yang baik (55\%) dikarenakan latar belakang penagalaman dan tingginya tanggung jawab personal. kepatuhan perawat dalam mencegah terjadinya VAP pada pasien yang terpasang ventilator, sehingga akan membentuk sikap perawat yang sesuai dengan standar perawat yang seharusnya, misalnya Tindakan pencegahan kolonisasi bakteri di orofaring dan saluran pencernaan seperti 
melakukan suction dengan 10 di antaranya memiliki skor memperhatikan teknik seteril, CPIS 6, dan 3 di antaranya pemberian $\mathrm{O}_{2}$ dengan konsentrasi memiliki skor CPIS 7.

tinggi sebelum suction, penggunaan kateter suction sekali pakai, dan tingginya sifat peduli terhadap masalah yang dialami pasien misalnya melakukan tindakan suction pada pasien yang banyak mengeluarkan sekret untuk mencegah timbul masalah pada pasien tersebut, suction yang dilakukan sesuai dengan SOP yang telah ada, perawat juga selalu mencuci tangan sebelum dan sesudah melakukan tindakan, serta kesadaran yang sudah maksimal dalam menjaga keseterilan dalam suatu tindakan kepada pasien. Tindakan penceghan VAP lainnya yaitu Tindakan pencegahan untuk mencegah aspirasi ke paru-paru dengan menyapih dan ekstubasi dini, dan perlakuan posisi semi fowler telah dilakukan perawat sesuai dengan SOP.

Angka VAP berdasarkan skor CPIS

Pada penelitian ini didapatkan bahwa 13 sampel total memiliki skor CPIS $\geq 6$. Dari 12 sampel, Kejadian VAP bisa dilihat dengan penilaian Clinical Pulmonary Infection Score (CPIS). Penilaian CPIS awal dilakukan dalam 48 jam sejak pertama kali pasien terintubasi dan menggunakan ventilasi mekanik di ICU dan pemeriksaan mikrobiologi dilakukan jika terdapat gejala klinis. Selanjutnya penilaian CPIS dilakukan berkala. Biakan kuman diambil berdasarkan teknik protected specimen brush, bronchoalveolar lavage, ataupun blind suctioning sekret bronchial (Sirvent, 2003).

CPIS merupakan sistem multi faktorial dalam menegakkan VAP pada penderita dengan pemakaian ventilator mekanik. Skor total CPIS dimulai dari 0 sampai 6 berdasarkan nilai pengukuran suhu tubuh, leukosit, sekret trakea, fraksi oksigenasi, foto torak. Bila dari hasil pemeriksaan komponen tersebut didapatkan nilai $\geq 6$, maka dapat dinyatakan sebagai diagnosis VAP (Pugin et al dalam Sirvent, 2003). 
Menurut Luna (2003) penilaian CPIS meliputi beberapa komponen yaitu suhu tubuh, leukosit, sekret trakea, fraksi oksigenasi, pemeriksaan radiologi. Dalam penilaian CPIS klasik disertai pemeriksaan mikrobiologi, sedangkan penilaian CPIS modifikasi tanpa disertai pemeriksaan kultur. Hasil penelitian ini sesuai dengan penjelasan di atas. Hal ini juga didukung oleh Koenig dan Truwit (2006) yang mengatakan bahwa skor CPIS $\geq 6$ memiliki sensitivitas $93 \%$ dan spesifisitas $100 \%$.

\section{ANALISA BIVARIAT}

Hubungan pengetahuan perawat tentang pencegahan Ventilator Associated Pneumonia (VAP) dengan peningkatan angka VAP di Ruang ICU RS Sari Asih Karawaci Tangerang

Hasil penelitian berdasarkan analisis univariat dapat dilihat bahwa pengetahuan perawat dengan kategori baik sebanyak 10 orang (77\%), dengan tidak adanya peningkatan angka VAP sebanyak 9 orang (90\%) dan sisanya sebanyak 1 orang (10\%) dengan ada peningkatan angka VAP. Sedangkan pengetahuan perawat dengan kategori kurang sebanyak 3 orang (23\%), dengan adanya tidak ada peningkatan angka VAP sebanyak 1 orang (33.3\%) dan sisanya sebanyak 2 orang $(66.7 \%)$ dengan ada peningkatan angka VAP. Hasil analisis secara statistik menunjukkan bahwa nilai independent t-test didapatkan nilai $\mathrm{p}$ value $<\alpha$ yaitu $0.000<0.05$ dengan tingkat Confidence Interval (tingkat kepercayaan) $95 \%$ artinya Ho ditolak. Maka dapat disimpulkan adanya hubungan yang signifikan antara pengetahuan perawat tentang pencegahan Ventilator Associated Pneumonia (VAP) dengan peningkatan angka VAP di Ruang ICU RS Sari Asih Karawaci Tangerang.

Wiryana (2007) menyatakan meskipun VAP memiliki beberapa faktor risiko, intervensi keperawatan banyak berperan dalam mencegah kejadian VAP. Ada dua cara pencegahan yaitu tindakan pencegahan kolonisasi bakteri di orofaring dan saluran pencernaan (mencuci tangans sebelum dan sesudah melakukan tindakan terhadap pasien, suction, oral 
dekontaminasi,Tindakan pencegahan untuk mencegah aspirasi ke paruparu, posisi semifowler, perubahan posisi tidur)

Tindakan suctioning endotrakeal merupakan faktor resiko terjadinya VAP jika dalam pelaksanaan mengabaikan kesterilan dan tidak berdasarkan Standar Operasional Prosedur (SOP). Berdasarkan penelitian yang dilakukan oleh Budi et al. (2009) di suatu rumah sakit di Yogyakarta didapatkan data bahwa hanya $44 \%$ perawat yang taat dalam pelaksaan tindakan suction, selebihnya tindakan suction perawat belum sesuai dengan SOP. Hal yang sama di sampaikan peneliti di RSUP Dr.Kariadi Semarang (2010), 50\% dari 10 perawat yang melakukan suction di ruangan ICU tidak berdasarkan SOP yang ada (Wiyoto, 2010). Hal ini tidak sesuai dengan penelitian ini, dimana sebagian besar responden sudah memilki pengetahuan yang baik tentang pelaksanaan suction sesuai SOP.

Pemakaian ventilator merupakan suatu bentuk tindakan pemasangan ETT dalam jangka panjang yang perlu tindakan keperawatan intensive untuk mencegah terjadinya komplikasi ventilator mekanik antara lain terjadinya VAP, volutrauma, gangguan kardio vaskuler, gangguan saluran pencernaan, sumbatan jalan napas, gangguan fungsi ginjal, gas traping dan ketidak selarasan pasien dengan ventilator. Untuk itu, diperlukan tingkat pengetahuan dan sikap yang profesional dari seorang perawat dalam merawat pasien yang terpasang ventilator (Purnawan dan Saryono, 2010)

Sebaliknya pada penelitian ini didapatkan tingkat pengetahuan perawat ICU di RS Sari Asih Tangerang sebagian besar dalam kategori baik (77\%). Menurut peneliti tingginya tingkat pengetahuan responden akan mempengaruhi pola pikir responden yang telah terpapar informasi dari lingkungan, pengalaman kerja dan pelatihan khusus yang dijalani. Saat seseorang menerima suatu informasi, secara otomatis pola pikir akan merespon dan menseleksi informasi tersebut dalam hal ini tentang pencegahan VAP sehingga semakin baik tingkat pengetahuan perawat tentang pencegahan VAP maka akan 
semakin kecil kemungkinan kejadian VAP pada pasien di ICU

\section{Kesimpulan}

Berdasarkan hasil penelitian yang telah dilakukan dan disajikan pada bab sebelumnya maka diperoleh kesimpulan mengenai "Hubungan Pengetahuan Perawat Tentang Pencegahan Ventilator Associated Pneumonia (VAP) Dengan Peningkatan Angka VAP di Ruang ICU RS Sari Asih Karawaci Tangerang" sebagai berikut :

1. Distribusi frekuensi tingkat pengetahuan tentang pencegahan Ventilator Associated Pneumonia (VAP) sebagian besar dalam kategori baik (77\%).

2. Distribusi frekuensi kejadian Ventilator Associated Pneumonia (VAP) dengan angka CPIS $<6 \mathrm{di}$ Rumah Sakit Sari Asih Karawaci Tangerang yaitu sebanyak 10 orang $(77 \%)$

3. Ada hubungan yang signifikan tingkat pengetahuan tentang pencegahan Ventilator Associated Pneumonia (VAP) dengan peningkatan angka VAP di Ruang ICU RS Sari Asih
Karawaci Tangerang dengan nilai $p$ value $0.000<0.05$

\section{Referensi}

American Association of Care Nurses (AACN). (2007). Core curriculum for critical care nursing. $\quad\left(7^{\text {the }} \mathrm{e}\right) . \quad$ : W.B. Saunders Company. America

AJCC.,American Journal of Critical Care,diakses pada tanggal 12 Januari 2016 dari http://ajcc.aacjournals.org

Arikunto,Suharsimi. (2001).Prosedur Penelitian: Suatu Pedekatan Praktek. Edisi Revisi V. Yogyakarta: Rineka Cipta.

Arikunto.(2006).Prosedur Penelitian Pendekatan Praktek. Jakarta: Rineka Cipta.

American Thoracic Society and the Infectious Diseases Society of America. ATS/IDSA Guidelines (2004). Guidelines for the management of adults with HAP, VAP, and HCAP Am J Respir Crit Care Medicine

A.Aziz Alimul Hidayat. (2007), Metode Penelitian Keperawa tan dan Teknik Analisis Data,Jakarta,Salemba Medika

Augustyn, B. (2007). VentilatorAssociated Pneumonia Risk Factors and Preventions. http://aacn.org/WD/CETests/Me dia/C0742.pdf.

Augustyn,B. Ventilator-Associated Pneumonia Risk Factors and Prevention.Available: $\quad \mathrm{h}$ //aacn.org/WD/CETests/Med 10 C0742.pdf.(Accessed: August 12, 2015); 2007 
Buisson CB.Antibiotic therapy of Ventilator Assosiated Pneumonia.Chest 2003 ;123:670-3

Cindy L Munro., Marry Jograp., Debora J. Jones., Donna K Mc Clish., Curtis N Sessler. (2009) Chlorhexidin, Toothbrushing and Preventing Ventilator Associated Pneumonia in Critically Ill Adult. American Journal of CriticalCare. 18:428437

Cleveland Clinic: Cleveland, OHMartono. (2008). Caring Practices in Reducing PreOperating Anxiety as Perceived by Surgical Nurse and Patients in

Banyumas, Central Java, Indonesia.

Dahlan, Zul (2006). Tinjauan Ulang Masalah Pneumonia yang didapat di Rumah Sakit Bandung : Tidak dipublikasikan

Data Kepegawaian Instalasi Perawatan Intensif (IPI) RS. Sari Asih Karawaci Tangerang (2015).Banten. Tidak dipublikasikan.

Dudut, T. (2003). Asuhan Keperawatan Klien dengan Ventilator. Diperoleh tanggal 3 juni 2012 dari http://repository.usu.ac.id/bitstre am/12345678 9/3600/1/keperawatan-dudut. pdf

Ernawati, Ni Luh Ade Kusuma (2006) Faktor - Faktor yang Berhubungan dengan Kejadian Infeksi Nosokomial Pneumonia pada Pasien yang Terpasang Ventilator di Ruang Intensive Care Unit Rumah Sakit Dr.Kariadi Semarang. http://keperawatan.undip.ac.id. Diunduh 15 Januari 2011
Ewig E,Baurer T,Tores A. The Pulmonary Physycian in Critical Care : nosocomial pneumonia.Thorax 2002 :366 71

Green,W,Lawrence.et.al,Health Education Planing A Diagnostik Approach,The Johns Hapkins University: Mayfield Publishing Company,2005

Hudak, Gallo. (2007). Keperawatan Kritis Pedekatan Holistik Edisi VI. Jakarta: EGC. Hurlock. (2002). Pembagian umur berdasarkan perkembangan Diperoleh tanggal 20 juli dari http://repository.usu.ac.id/bitstre $\underline{\mathrm{am} /}$

123456789/33101/3/Chapter\%2 0II.pdf

Ibrahim EH., Ward S., Sherman G., Kollef, M.H. (2000). A Comparative Analysis of Patients with Early-Oset VS Late-Onset

Nosocomialpneumonia in The ICU Setting. Chest. 117:143442Kementerian Kesehatan Republik Indonesia. (2010). Pedoman HCU dan ICU Indonesia. Bakti Husada

Instalasi Rekam Medik RS Sari Asih Karawaci Tangerang. (2015). Data Pasien yang Diintubasi di ICU RS Sari Asih Karawaci Tangerang Tahun 2015

Joseph, N. M., Sistla, S., Dutta, T. K., Badhe, A. S, Parija, S. C. (2010). Ventilator-Associated Pneumonia : A Review. Diakses tanggal 04 September 2015. http://xa.yimg.com/kq/groups/1 6298323/2119309964/ name/Review+NAV,+EJIM+20 $\underline{10 . p d f}$ 
Kollef MH,The Prevention of Ventilator Associated Pneumonia. $\mathrm{N}$ Eng $\mathrm{j}$ Med 2005;340:627-34

Kementrian Kesehatan Republik Indonesia.(2010).Pedoman $H C U$ dan ICU Indonesia, Bakti Husada

Luna, C. M., Blanzaco, D., Niederman, M. S., Matarucco, W., Baredes, N. C., Desmery, P.,Palizas, F., Menga, G., Rios, F., Apezteguia, C. (2003). Resolution of VentilatorAssociated Pneumonia: Prospective Evaluation of the Clinical Pulmonary InfectionScore as an Early Clinical Predictor of Outcome. Diakses tanggal 01 Agustus 2015 dari http://medscape.com/viewarticle $\underline{1450885}$

Mandell LA, Wunderink RG, Anzueto A, Bartlett JG, Campbell GD, Dean NC, et.al (2007). Infectious Diseases Society of Americal American Thoracic Society Consensus Guidelines on the Management of Community-Acquired

Pneumonia in Adults. Clinical Infectious Diseases.

Martono (2008),Infeksi Nosokomial Problematika Dan Pengenda liannya ,SalembaMedika, Yogyakarta

Niederman, M.S., Craven, D.E., Bonten, M.J., etal.( 2005) American Thoracic Society Documents: Guidelines For The Management of Adults With Hospital-Acquired, VentilatorAssociated, and HealthcareAssociated Pneumonia. Am J.
Respir Crit Care Med. 171:388416

Notoatmojo, S. (2007). Metodologi Penelitian Kesehatan. Jakarta : PT Rineka Cipta

Nototmodjo,S (2007),Promosi Kesehatan dan Ilmu Perilaku, Jakarta:Rineka Cipta

Nursalam, S. P. (2001). Metodologi Riset Keperawatan. Jakarta: Sagung Seto

Nursalam,Konsep \& Penerapan Metodologi Penelitian Ilmu Keperawatan,Salam Medika,Jakarta,2003

Pineda LA, Saliba RG, El Solh AA (2006). Effect of Oral Decontamination With Chlorhexidine On The Incidence Of Nosocomial Pneumonia Meta Anlysis Critical Care.

Porzecanski I., Bowton, D.L. (2006). Diagnosis And Treatment of Ventilator-Associated

Pneumonia. Chest .. 130:597604.

PPI RSUD Arifin Achmad. (2015). Data Kejadian VAP DI ICU RS. Sari Asih Karawaci Tangerang. Tidak dipublikasikan.

Purnawan, Iwan, Saryono ( 2010 ). Mengelola Pasien Dengan Ventilator Mekanik. Jakarta : Rekatama

Perhimpunan Dokter Paru Indonesia,(2003),Pneumonia Nosokomial Pedoman Diagnosis dan Penatalaksa naan di Indonesia

Roger D, Engel, James, F, Blackwell, dan Paul W. Miniard. (2005). 
Konsep Perilaku. Edisi Keenam. Jilid 1. Penerbit Binarupa Aksara. Jakarta

Saanin (2006). Hubungan Pengetahuan dan Sikap Perawat dengan Tindakan Pencegahan Ventilator Associated Pneumonia (VAP) di Unit Perawatan Intensif $R S \quad D r$. M.Djamil Padang.

Schleder, B.J. (2003) Taking Charge Of Ventilator-Associated

Pneumonia. Nurse Manage .. 34(8):29-32. 2003; 34 (8) :2932

Sirvent JM, Vidaur L. Gonzalez S, Castro, Battle J, et al. (2003) Microscopic examination of intrecellular organism in protected bronchoalveolar mini lavage fluid for the idgnosis of ventilator associated pneumonia. 123:518-23

Smeltzer \& Bare. (2002). Keperawatan Medikal Bedah. Jakarta: EGC

Soedono (2007). Pedoman Manajerial Pencegahan dan Pengendalian Infeksi di Rumah Sakit dan Fasiltas Kesehatan Lainnya. PERDALIN. Jakarta

Sugiyono (2005),Statistik Untuk Penelitian,Cetakan

kelima,Bandung:CV.Alfabeta

Tan, J. C., Banzon, A. G., Ayuyao, F., Guia T. D. (2007). Comparison of CPIS (Clinical Pulmonary Infection Score and Clinical Criteria in the Diagnosis of Ventilator-Associated

Pneumonia in ICU Complex Patiens. Diakses tanggal 20 Agustus 2015,darihttp://phc.gov.ph/about -phc/journals/pdf/tan.pdf.

Tablan OC,Anderson LJ,Besser R,et al : Guidelines for preventing health-care associated pneumonia.Recommendations of $C D C$ and the health care infection control practices advisory committee.CDC 2004;53 (RR 03):1-36

Tietjen, Linda, dkk. (2004). Panduan Pencegahan Infeksi Untuk Fasilitas. Pustaka Sarwono Prawiroharjo. Jakarta

Torres A., Gatell J.M., E Aznar., et al. (1995) Re-Intubation Increases The Risk of Nosocomial Pneumonia In Patients Needing Mechanical Ventilation. Am J Respir Crit Care Med. 152(1):137-141. 1995; 152 (1) :137-141.

Wiryana, Made. (2007) Ventilator Associated Pneumonia. Bagian/ SMF Ilmu Anestesi dan Reanimasi, FK Unud/ RSUP Sanglah Denpasar. I Peny Dalam, Volume 8 No 3

Wenzel RP,Sahm DF,Thornsberry C,Draghi DC,Jones MF,Karlowsky JA,.In vitro susceptibilities of gram negative bacteria isolated from hospitalized patients in four European countries, Canada, and the United States in 2000-2001 to expanded-spectrum cephalosporins and comprator antimicro bials:implications for therapy antimicrob agents chemother, 2003;47:30893098http://www.klilpdpi.com/ko nsensus/pnenosokomial/pnenoso komial.pdf (Akses pada 30 Oktober 2014) 
